\title{
Collaborative information behaviour of butterfly farmers in Eastern Usambara Mountains, Tanzania
}

\author{
Faraja Ndumbaro ${ }^{1}$ and Stephen M. Mutula ${ }^{2}$ \\ 1 Information Studies Programme, College of Social Sciences, \\ University of Dar es Salaam P. O. Box 35092, Dar es Salaam, TANZANIA \\ ${ }^{2}$ Information Studies Programme, University of KwaZulu-Nata \\ I Private bag X01, Scottsville, 3209, SOUTH AFRICA \\ e-mail: ndumbaro.faraja@udsm.ac.tz; mutulas@ukzn.ac.za (corresponding author)
}

\begin{abstract}
This study investigated collaborative information behaviour of butterfly farmers working in the Integrated Conservation and Development Project (ICDP) located in the neighbourhood of Amani Nature Reserve, Tanzania. The study was motivated by the fact that despite extensive studies on collaborative information behavior in such domains as education, medical, and the military there is a knowledge gap in our understanding of farmers' collaborative information behavior in the context of collaborative farming. The investigation sought to investigate the shared information needs of farmers in the ICDP project; the patterns of collaborative seeking, sharing and exchanging information of farmers in ICDP; and how butterfly farmers, ANR and TFCG officials in ICDP perceive the link between collaborative farming and collaborative information behaviour. The study applied qualitative approach in analysing group information behaviour guide by the social capital theoretical lens. The data were collected through interviews and observation and analysed using thematic categorisation. The findings of the study revealed that collaborative farming practices, formal structure of relationship between farmers and characteristics farmers were the factors which shaped the way farmers sought, shared and exchanged knowledge and information. It was further revealed that the interplay between collaborative information behaviour and collaborative farming practices were strong enough to support effective implementation of ICDP goals. The study has demonstrated the importance of using social capital factors particularly group structure, embedded resources and shared goals to understand human information behaviour. The findings also shed light to policy and decision makers in the sectors of agriculture and natural resources on the importance of understanding the relationships between information, conservation and development. With regard to practice, the findings have implications to stakeholders engaging on different ICDPS in understanding the role of information on promoting integrated and sustainable agricultural practices.
\end{abstract}

Keywords: Butterfly farming; Collaborative information behaviour; Information needs; Information seeking; Knowledge sharing.

\section{INTRODUCTION}

Butterfly farming is not a new practice. Studies show that for many years farmers in some countries with tropical rainforest have been engaging in butterfly farming (Small 2004; Sumodan 2004). These countries include tropical countries of Africa and Latin America, 
such as Papua New Guinea, Costa Rica, Kenya, South Africa, Madagascar, Uganda, Peru and Malaysia. In practice, butterfly farming involves breeding and rearing of pupae and adult butterflies in a protected environment. Butterfly breeders capture male and female butterflies from forests and keep them in enclosed areas such as cages or greenhouses. Initially farmers are supposed to prepare habitant for butterflies which involves planting trees which provide food for larvae and nectar for adult butterflies (Sumodan 2004). Female butterflies are then left to lay eggs which hatch and develop to caterpillars, pupae or sometimes adult butterflies. The pupae are then collected and sold for exhibitions and other social events.

Unlike other farming practices, butterfly farming is environmentally and ecologically friendly. Butterfly farming offers both environmental and economic benefits as it combines business and conservation of natural habitat (Schlaepfer 2006) and generation of income to butterfly breeders. Successfully butterfly farming relies on native vegetation as the source of food for larvae and nectar for the adult butterfly. Ecologically butterflies are agents of pollination as when feeding on nectars, they also help plants pollination process.

Butterfly farming also provide an alternative source of income to farmers living adjacent to forest resources. It is estimated that globally the butterfly trade contributes to about USD 100 millions (Rich, Rich and Chengappa, 2014). Butterfly farming is also a less intensive farming activity; hence it gives farmers more time to engage in other economic and social activities.

\section{Butterfly Farming in Tanzania}

Increasing human population growth, escalating poverty, high dependence on land-based economy, together with illegal forest logging and mining activities, have led to excessive exploitation and unsustainable use of natural resources within and surrounding Amani Nature Reserve (Amani Nature Reserve 2012). In addressing some of these problems, the Tanzania Forest Conservation Group (TFCG), a Non-Governmental Organization introduced butterfly farming projects in some villages neighboring Amani Nature Reserve. The projects which started in 2001 are based on the Integrated Conservation and Development model. In this model butterfly farming is used as a way of providing alternative income for local communities and conserving forests (Morgan-Brown et al. 2009). Farmers with the support from Tanzania Forest Conservation Group are involved in breeding and selling pupae in Europe and America for both live exhibitions and dried butterfly collections.

\section{Information Seeking in Farming Practices}

Successful farming practices are highly dependent on relevant, accurate, timely and adequate information relating to such issues as farming technologies, weather and rainfall seasonal changes, marketing strategies and prices. Understanding the individual or collaborative information behaviour of farmers is of critical importance. Information behaviour refers to different ways in which human beings interact with information including the way people seek and use information (Bates 2010). In contrast, collaborative information behavior is a generic term that is used to denote a totality of human behaviour exhibited when two or more individuals collaborate in identifying information needs, seeking, evaluating, sharing and applying information in solving a problem (Saleh 2012). The relationship between collaboration and information behavior is reciprocal. In this regard, Shah (2013) discusses two ways of looking at the relationship between 
collaboration and information behavior. While collaboration may be used to solve information seeking problems which are too complex to be addressed by the individual, information seeking can be used to facilitate collaborative work (Shah 2013). In the context of collaborative farming, the concept collaborative information behavior includes wide range of information-related behavioral activities demonstrated by farmers in the course of satisfying shared agricultural related information needs and accomplishing farming related activities. These social information-related behavioral activities include collaborative information seeking, sharing and exchanging of information and collaborative information use.

\section{CONTEXT OF THE STUDY}

Increasing human population growth, escalating poverty, high dependence on land-based economy, together with illegal forest logging and mining activities, have led to excessive exploitation and unsustainable use of natural resources within and surrounding Amani Nature Reserve. Consequently, farmers and the Tanzania Forest Conservation Group are collaborating in breeding and selling pupae in Europe and North America for both live exhibitions and dried butterfly collections as an alternative land-based economy.

Amani Nature Reserve (ANR) is part of Eastern Usambara Mountain ranges located in Muheza district, Tanzania. The reserve is located between longitudes $5^{\circ} 14^{\prime} 10^{\prime \prime}-5^{\circ} 04^{\prime} 30^{\prime \prime}$ and latitudes $38^{\circ} 30^{\prime} 34^{\prime \prime}-38^{\circ} 40^{\prime} 06^{\prime \prime}$ (Amani Nature Reserve, 2012). The area is one of the world's great "biodiversity hot spot" (Jambiya and Sosovele 2001; Vihemäk 2006) endowed with a variety of forest and wildlife resources. Figure 1 provides the map of the ANR and surveyed villages.

The butterfly farming practices around ANR is a typical example of collaborative farming practice involving mainly two actors who share similar goals and expectations. The successful implementation of the collaborative butterfly farming venture is dependent on the actors to be fully equipped with knowledge, skills as well as relevant, accurate, adequate, appropriate and timely information. Extensive studies that have been done on collaborative information behavior have focused on different domains, such as education (Harrison 2009; Saleh 2012), medicine (Reddy 2003; Hertzun 2010) and military (Sonnenwald and Pierce 2000; Prekop 2002). Despite such extensive coverage, there is still a knowledge gap in our understanding of farmers' collaborative information behavior in the context of collaborative farming and Integrated Conservation and Development Project (ICDP). This study therefore, attempts to address part of this gap by investigating collaborative information behaviour of butterfly farmers working in a collaborative butterfly Integrated Conservation and Development Project. The study focuses on four aspects of collaborative information behaviour: The study focuses on four aspects of collaborative information behaviour: shared information need, collaborative information seeking, information sharing and collaborative information use. 


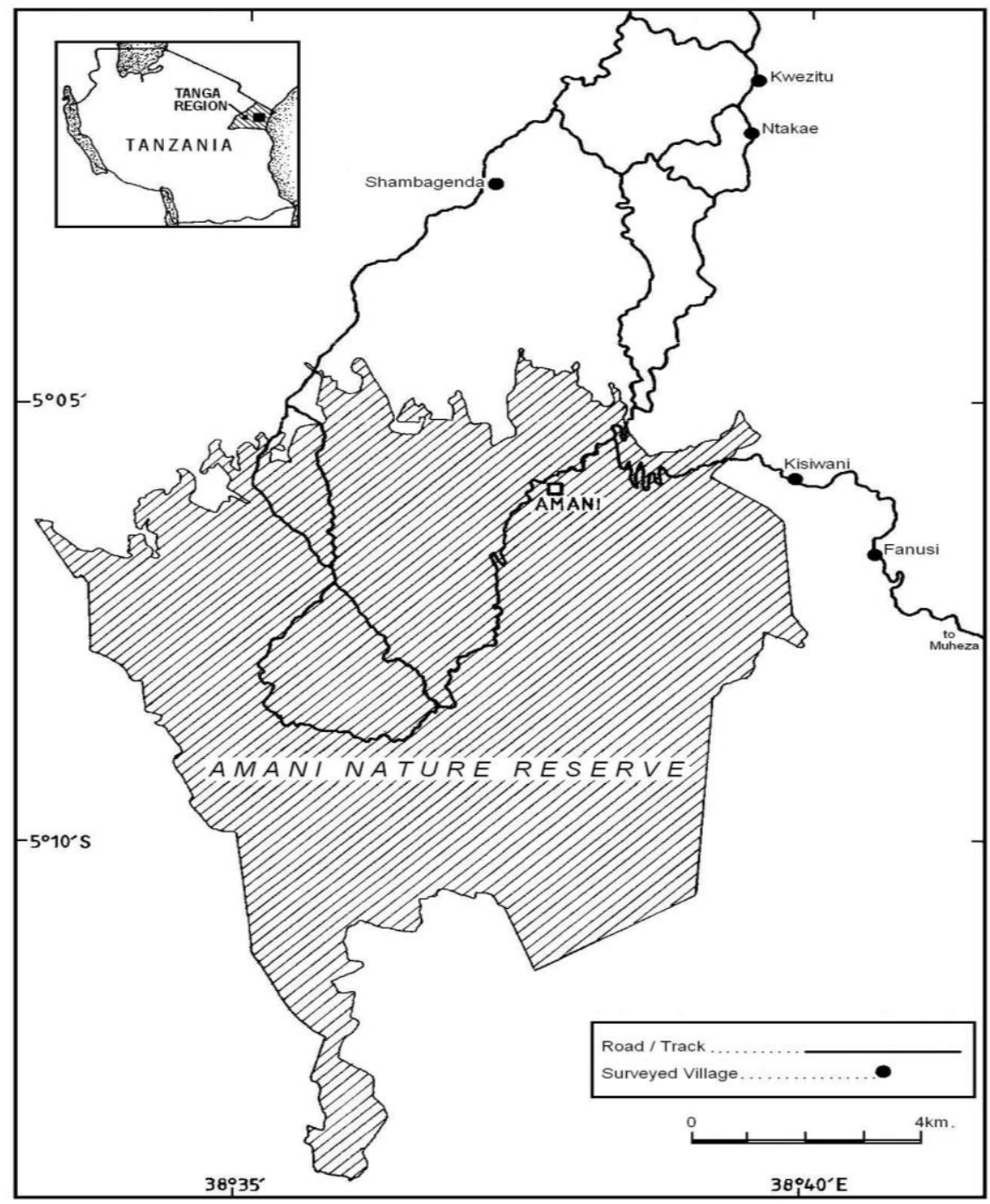

Figure 1: A map showing locations of surveyed villages adjacent to ANR (Source: Cartographic Unit, University of Dar es Salaam, 2015)

\section{OBJECTIVE AND RESEARCH QUESTIONS}

The objective of this study is to investigate collaborative information behaviour of farmers working in Integrated Conservation and Development (ICDP) butterfly project in four villages located in the neighbourhood of ANR, Tanzania. The study is guided by the following research questions:

1. What are the shared information needs of farmers in the ICDP project?

2. In what patterns do the farmers in ICDP collaboratively seek, share and exchange information?

3. How do butterfly farmers, ANR and TFCG officials in ICDP perceive the link between collaborative farming and collaborative information behaviour? 


\section{THEORETICAL LENS}

This study is informed by the social capital theoretical lens. Although there is no single unified theory of social capital, there are a few concepts that are used to describe the idea of social capital. As a concept, social capital is described as dense of networks of social interactions which encourage emergence of social trust and norms of reciprocity (Putnam 1995). Social capital also is used to mean resources embedded in a social structure (Lin 2001) and a product of social relation and structural asset based on relationship between people (Widén-Wulff et al. 2008). Furthermore, Häuberer (2011) describes social capital as a relationship of mutual trust, authority and prescriptive norms.

In this study, the social capital concepts have been used to illuminate and provide the theoretical lens for the analysis of how existing structure of relationships, network of interactions, norms, farmers' expectations and trust shape collaborative information behaviour of butterfly farmers. Specifically, the framework has been used to provide lens on how farmers collaboratively seek, share and exchange agricultural related information and knowledge. Table 1 illustrates how the constructs in the research questions map onto the social capital concepts.

Table 1: Mapping of research questions key concepts of social capital framework

\begin{tabular}{|c|c|}
\hline Main Research question & Key concepts of social capital \\
\hline $\begin{array}{l}\text { 1. What is the collaborative information } \\
\text { behaviour of butterfly farmers working in } \\
\text { Integrated Conservation and Development } \\
\text { Project? }\end{array}$ & $\begin{array}{l}\text { Social structure (social network), } \\
\text { embedded (Social) resources, social ties } \\
\text { (weak or strong social ties), trust (shared } \\
\text { norms) }\end{array}$ \\
\hline Specific research question & Key concepts of social capital \\
\hline $\begin{array}{l}\text { 1. What are the shared information needs of } \\
\text { farmers in the ICDP project? }\end{array}$ & $\begin{array}{l}\text { Shared goal (outcome), shared interest, } \\
\text { shared problems (activities) }\end{array}$ \\
\hline $\begin{array}{l}\text { 2. In what patterns do the farmers in ICDP } \\
\text { collaboratively seek, share and exchange } \\
\text { information? }\end{array}$ & $\begin{array}{l}\text { Interpersonal communication, social } \\
\text { interaction, }\end{array}$ \\
\hline $\begin{array}{l}\text { 3. How do butterfly farmers, ANR and TFCG } \\
\text { officials in ICDP perceive the link between } \\
\text { collaborative farming and collaborative } \\
\text { information behaviour? }\end{array}$ & $\begin{array}{l}\text { Social influence, construct knowledge } \\
\text { (social construction) }\end{array}$ \\
\hline
\end{tabular}

\section{LITERATURE REVIEW}

This review of literature reflects the cross-cutting nature of information behavior, collaborative information behavior, butterfly farming and forest conservation. There are number of studies that have been done on farmers' information behavior focusing on information needs of farmers (Lwoga, Ngulube and Stilwell 2010; Byamugisha, IkojoOdongo and Nansinyama 2010; Elly and Silayo 2013), information seeking behavior (Lwoga, Ngulube and Stilwell 2010) and provision of agricultural information for development (Meyer 2003). Other dimensions studied include access and use of agricultural knowledge and information (Fawole 2008; Lwoga, Stilwell and Ngulube 2011; Mwalukasa 2012). Despite the fact that these studies have been conducted in different settings, different farming activities and study populations, findings obtained from these studies have 
revealed some commonalities. For example, most of the studies have established a link between information needs of farmers with factors such as farming enterprises, activities and tasks as well as geographical location of farmers (Matovelo, Msuya and de Smet 2006; Byamugisha, Ikojo-Odongoand and Nansinyama 2010; Munyua and Stilwell 2010; Lwoga, Stilwell and Ngulube 2011; Elly and Silayo 2013). Findings from other studies have revealed that gender, age, marital status (Fawole 2008) and level of education (Katungi, Edmeades and Smale 2006) influence farmers' information needs and choice of information sources.

Besides, studies of farmers' information behavior have also established that farmers more often rely on people as the major source of agricultural information (Tadesa 2008; Munyua and Stilwell 2011; Elly and Silayo 2013). Using people as the main source of information by farmers has been attributed to factors such as dominance of oral culture among farming communities particularly in rural areas, lack of harmonization between indigenous knowledge and modern information resources (Meyer 2003), failure to incorporate new technologies for disseminating agriculture information to farmers knowledge systems and weak linkages between farmers and other actors in agricultural knowledge information system (Munyua and Stilwell 2010).

Information or knowledge sharing and exchange are important components of collaborative information behavior. This is emphasized by Talja (2002) and Davies (2013) who see information sharing as natural and inevitably linked to collaborative information behavior. Only a few studies on farmers' information behavior have focused on understanding information and knowledge sharing behavior of farmers. Among these studies are those of Tadesa (2008), Munyua and Stilwell (2010), Iraba and Venter (2011), and Mashavave et al. (2013). While Munyua and Stilwell found that farmers in Kenya mainly shared information through trainings, meetings, demonstrations and one to one oral discussions, Mashavave et al. (2013) observed that farmers in Zimbabwe shared information through farmers' exchange visits, seed fair, workshops and agricultural shows. Also, Tadesa (2008) found that farmers in Ethiopia shared agricultural information and knowledge through farmer's field day, individual extension advisory, mass media and visiting farmer's market place. In exploring the role of low cost technology in sharing information Iraba and Venter (2011) observed that there is a potential of using inexpensive technologies to promote both access and sharing of market related information in South Africa.

Much of the previous works in butterfly farming have focused on the relationships between farming, community development and natural resources conservation. These studies include Morgan-Brown (2007) who investigated differences in conservation behavior between butterfly farmers and non-butterfly farmers in two villages of Kwezitu and Msasa. Similarly, Morgan-Brown et al. (2009) examined how farmers' perceptions and benefits gained from butterfly farming changed their conservation behaviors positively. Generally, these two studies found positive relationships between butterfly farming and conservation behavior where majority of the farmers were more likely to participate in conservation (Morgan-Brown 2007; Morgan- Brown et al. 2009). Other studies have focused on impact of ICDPs to the local communities and conservation of natural resources around Amani nature reserve. These include study of Engh (2011) and Jambiya and Sosovele (2001). Engh (2011) assessed the impact of ICDP on butterfly farming and other projects around ANR and found that while the projects contributed to the improvement of livelihood and conservation, the scale of the projects is not wide enough. Jambiya and 
Sosovele (2001) studied the relationship between conservation effort and improvement of livelihood among local communities living adjacent to the ANR. The findings of the study showed that local communities living adjacent to ANR have yet to benefit from natural resources in the area.

Generally, the literature reviewed has shown that there is paucity of studies on collaborative information behavior of farmers. A few studies such as Munyua and Stilwell (2010), Iraba and Venter (2011), and Mashavave et al. (2013) have only included some aspects of collaborative information behavior while majority of the studies on agricultural information behavior (Fowole 2008; Matovelo, Msuya and de Smet 2006; Byamugisha, Ikojo-Odongo and Nansinyama 2010; Mwalukasa 2012, Elly and Silayo 2013) have paid little attention to collaborative aspect of farmers' information behavior. intensive domain such as agriculture generally and butterfly farming in particular.

\section{METHOD}

The study employed a qualitative research approach in investigating collaborative information behaviour of butterfly farmers. This approach is in consistency with the purpose of the study which aimed at understanding farmers' collaborative information behavior within the contexts of ICDP.

Four villages of Kwezitu, Kisiwani, Ntakae and Shambangeda were included in the study (Figure 1). These villages were deliberately selected because unlike other villages, they have been involved in the butterfly farming practices since the inception of the projects. The study population also includes two institutions of Tanzania Forest Conservation Group (TFCG) and ANR. Within each village, butterfly farming is practiced in organized groups of farmers ranging from eight (8) to 12 farmers. The sample for the study consisted of four groups of butterfly farmers, one group selected from each group using simple random sampling technique. Three out of four groups consisted of nine (9) farmers each while one group had eight (8) farmers. The sample also includes two (2) Tanzania Forest Conservation group and two (2) ANR officials. TFCG and ANR officials were purposively selected because they are the one who provide technical advice to farmers. In addition to that, TFCG officials were also purposively selected because they are the one who coordinate project activities. The total sample size therefore consisted of 39 respondents.

Data collection was done for the period of 18 days from $23^{\text {rd }}$ April to $10^{\text {th }}$ May 2014. Data were collected using face to face interview and focused group discussion. Interviews for the ANR and TFCG officials were conducted in their respective offices. Focused group discussion for famers was conducted in the village offices of each village. Face to face interviews were conducted with key informants including TFCG officials and ANR conservationists. The aim was to ascertain officials' views and perceptions regarding the link between collaborative farming and collaborative information behaviour. Also, interviews were conducted with the intention of understanding the role of ANR and TFCG in support of farmers' access to information and facilitating information sharing. Focused group intended to gather information related to butterfly farmers' information needs, information seeking and sharing behaviour, and their perceptions and views regarding the link between collaborative farming practices and collaborative information behaviour. Focus group discussions were conducted involving four groups of butterfly farmers. These are existing groups of farmers who are working together in collaborative farming with 
eight (8) to nine (9) members in each group. Interview and focused group discussion were complemented by observation. Different collaborative behavioral activities related to farming were observed to understand their information needs and information sharing behavior. Farmers were observed while they were in the farms and when they were in meetings among themselves or with ANR and TFCG officials.

Data were collected using interview guide, focus group discussion guide and observation schedule. Data were analysis involved identification of themes and concepts based on research questions. Ranking measure has been used in analyzing views and opinions of respondents. Succinct summary of the findings has been also presented using figures and verbatim statements.

Different measures were taken to ensure the validity during data collection, analysis and interpretation. The use of social capital theoretical framework improved procedural validity of the study. The framework provides the theoretical lens during data collection; allows researchers to make reflexive accounts of farmers' observable group informationrelated behavioral patterns and relate the behavior with the broader context of the study. The use of multiple data collection techniques including observation, focus group discussion and key informants' face to face interviews intended to improve construct validity. During data analysis and interpretation data were compared with the existing related literature to improve interpretive validity.

To establish dependability or reliability during data collection and analysis, researchers ensured that different sources of unreliable measurements are eliminated. First, prior to actual data collection instruments were pre-tested on one group of butterfly farmers and two officials form TFCG and ANR. Second, interview guides and observation checklist were properly constructed to reflect research problem and research questions. Third, the use of multiple groups of farmers and inclusion of conservationists aimed at replicating, verifying and comparing the findings from different respondents hence enhancing dependability and consistency of the instruments.

\section{RESULTS}

The results presented and discussed in the following sub-sections are based on focus group discussions conducted with groups of farmers and individual face to face interviews with selected TFCG officials and ANR officials. Three thematic areas emerged from the analysis are used as the organising framework. These thematic themes are: (i) Information and knowledge needs related to collaborative farming and conservation activities; (ii) butterfly farmers' information seeking and sharing practices and (iii) farmers' views on the contributions of collaborative information behavioural practices to the implementation of ICDP's goals.

\section{Collaborative Information Behaviour of Butterfly Farmers}

The way butterfly farming practiced necessitated farmers to be equipped with wide range of information and knowledge related to farming, marketing and conservation. Farmers were asked to identify their agricultural related information and knowledge needs and discuss how such needs related to farming and conservation activities. The findings of the study indicated that butterfly farmers needed information and knowledge on how to prepare farming equipments, seasonal variations and abundance of butterflies, captives'

Page | 22 
fecundity as well as hatching and generation variations. Farmers also needed information and knowledge about types and characteristics of host plants, collection and storage of eggs, monitoring growth of larvae and pupae, common diseases and predators attacking butterflies and butterflies market related information. While farmers' information and knowledge needs were found to relate to farming activities, the findings from the study also established that there were indirect links between farmers' information and knowledge gap that existed especially with regard to forest conservation and planting of host plants.

Analysis of the findings also revealed that farmers' collaborative information behaviour was shaped by the nature of collaborative tasks, existence of formal structure which defined relationships, roles and division of works among farmers and other actors, differences in famers' information related skills as well as exposure to information sources and services. The study also found that the presence of formal structure of relationships established by TFCG determined both the way roles and tasks were distributed between farmers and other actors, and the way information was sought and shared. Factors such as differences in information related skills and knowledge among farmers and exposure to information sources and services made farmers' collaborative information seeking both complementary and integrative collaboration. Complementary information seeking behaviour was characterised by high division of labour and farmers' dependence on few knowledgeable individuals on information and knowledge related to market, butterfly abundance, seasonal variations, and reproductive behavior. Integrative collaborative information behaviour was common during joint working sessions such as farm visits, collection and storage of butterfly eggs and pupae and monitoring growth of larvae and pupae.

In terms of information sources, findings obtained from interviews showed that farmers were heavily relying on people including fellow farmers and TFCG staff as the main source of agricultural related information and knowledge. The fact that farmers had been engaging in farming activities for more than ten years, revealed that they had created an information and knowledge pool. With the existence of a culture of sharing information orally and the fact that farmers lived in proximity to each other, the most common ways of sharing information among farmers and between farmers and other actors were informal meetings and face to face conversations and farms visits. In terms of information and knowledge exchange, different methods were identified to be used, including the use of training workshops, formal and informal meetings and technical assistance provided by TFCG in collaboration with in collaboration with ANR staff.

\section{Collaborative Information Behaviour in the Implementation of ICDP Goals}

The study also sought to obtain farmers' views on the extent to which collaborative information practices and collaborative farming activities had contributed to the implementation of ICDP's goals in supporting sustainable farming, improving farmers' livelihood and conserving forests. Generally, it was found that that both farmers and other actors involved in the butterfly farming viewed butterfly farming practices as both economically and environmentally sustainable. In the group interview with farmers one respondent commented on the intersection between collaborative information behaviour and collaborative farming: "From the early stages of this project we were trained on the importance of planting trees as one of the conditions for establishing butterfly farms. Through training and 'shamba" visits we can now identify and plant different trees and other plants that are used by butterfly." 
It is evident from the above statement that while seeking information on appropriate host plants for butterfly farming was one of the farmers' information needs, having knowledge of suitable host plants contributed to the realization of ICDP's goal in general and collaborative farming in particular.

The views regarding knowledge and information sharing and exchange among farmers within the groups and beyond also emerged during the interview as one of the respondent reports: "Two years ago we travelled to Mombasa to learn from our neighbours who have long experiences on butterfly farming. They also visited us for the purpose of learning... the fact that some of the species are only available in Tanzania and some in Kenya and that the two environments are somewhat different we learnt a lot from each other."

Commenting on how farmers' access to information and knowledge from experts improved the sustainable use of natural resources and the extent to which project implementations have contributed to the improvement of farmers, one respondent from ANR insisted that: "Butterfly farming has improved farmers lives and increase community's sense of ownership to their resources"... We always assist them through training and visit their farms on regular basis. I am happy that farmers are now advocates of sustainable use of natural resources."

Figure 2 presents respondents' views with regards to the links between collaborative information behavioral activities and ICDP activities. Nine patterns which show relationships between collaborative information behavioral activities and ICDP activities were identified. The first category of opinions includes knowledge sharing and exchange, information sharing and exchange, existing formal structure of interactions among different actors, provision of technical assistances to farmers and farmers having opportunity to participate in group learning. This category contains group behavioral practices which facilitate realization of ICDP's goals. The second category consists of sets of outcomes of both collaborative information behavioral practices and implementation of ICDP. These are imposing suctions that restrict unsustainable use of natural resources, improving social services and farmers' livelihood and practicing ecologically and environmentally friendly farming.

Despite having common views on existence of positive relationship between collaborative farming, collaborative information behaviour and forest conservation, the results from the barometer used to measure farmers opinions showed some differences in terms of emphasis placed on certain factors. Figure 2 shows also the butterfly farmers' opinions of collaborative farming and collaborative information behaviour. The higher the number, the higher the influence of the variable on ICDP.

From the farmers' views, the most important factors that linked butterfly farming and collaborative information behaviour with ICDP success were ability of farmers to engage on collaborative learning, technical assistances provided by TFCG and ANR staff included: butterfly farming facilitates knowledge and information sharing and exchange, and nature of farming as naturally pro-conservation and environmentally friendly. In addition, TFCG and ANR officials were of the opinions that information and knowledge sharing, nature of farming which encouraged preservation of forests, provision of technical assistance to farmers and prescribed structure that guide the way different people in the project interacted with each other had to a large extent contributed to the attainment of project's goals. 


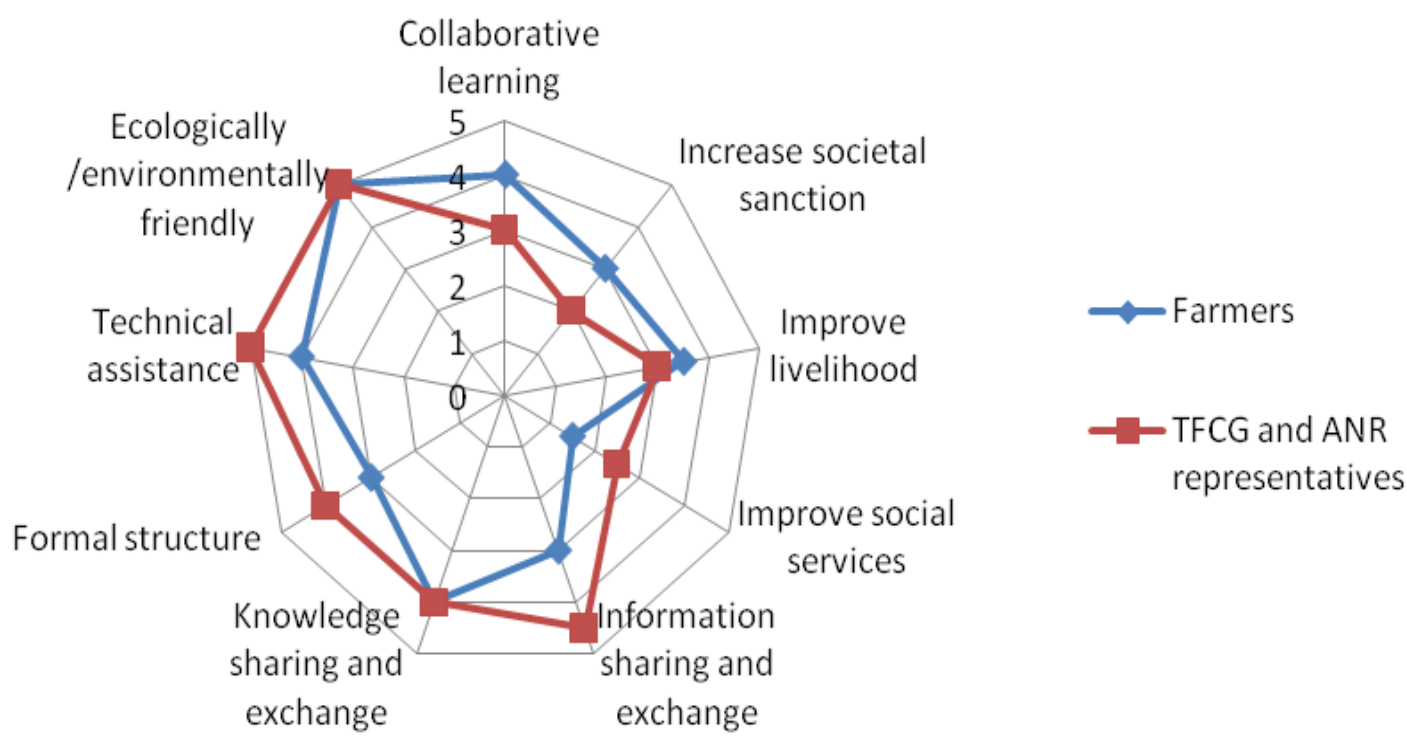

Figure 2: Opinions on the role of collaborative farming and collaborative information behaviour in the implementation of ICDP's goals.

\section{DISCUSSIONS}

The findings have shown that butterfly farming practices in villages around Amani Nature Reserve are inherently collaborative and require farmers to have access to information and knowledge related to various farming, conservation and marketing activities. Collaborative information needs of butterfly farmers have been found to be both diverse and dynamic in nature. The diversity and dynamic nature of farmers' information needs are attributed to the diverse nature of collaborative butterfly farming and the fact that collaborative butterfly farming involves multiple activities. The findings have shown that collaborative information needs of farmers are task specific. These tasks relate to both collaborative farming and forest conservation. The fact that farmers' information needs are associated with their farming activities has also been reported in previous studies of Aina (1991) and Elly and Silayo (2013). In terms of preferred sources of information, this study confirms the results from previous research where farmers were found to highly dependent on other farmers and officials within butterfly ICDP. This pattern of information seeking has been discussed by Meyer (2003) who described farmers' information behaviour in rural areas to be characterised by "information advising" from knowledgeable members within communities.

The findings of the study have confirmed that different aspects of social capital framework relate to the farmers' collaborative information behaviour particularly the way information and knowledge are sought, shared and exchanged among different people in the project. Social capital insists on the importance of norms of reciprocity and mutual benefits. The fact that farmers have shared information was noted to be the motivation behind their collaborative farming as well as the sharing of information and knowledge. It was found from the stakeholders that social incentives, particularly the desire to learn and share from 
each other's experiences, sense of group identity as well as economic incentives were some of the factors shaping collaborative information behaviour of farmers. It was also revealed that the existence of formal project structure had created strong network of relationships and division of roles and tasks among famers, butterfly farmers committee, ANR officials and TFCG. These are motivational factors that facilitate interactions, information and knowledge sharing and exchange. These findings corroborate those of Katungi, Edmeades and Smale (2006) who found that social capital, especially established social structure, played a significant role in sharing of information among rural farmers in Uganda. Similarly, Munyua and Stilwell (2009) found weak linkages among farmers in Kenya which inhibited information and knowledge sharing.

\section{CONCLUSION}

This study investigated collaborative information behaviour of butterfly farmers working in the Integrated Conservation and Development Project (ICDP). Qualitative approach and the social capital theoretical model were used as research design and the lens respectively. The data were collected through interviews and analysed using thematic categorisation. The findings revealed that collaborative farming practices and formal structure of relationship between farmers were the main factors which shaped the way farmers sought, shared and exchanged knowledge and information. The findings from this study have policy, theoretical and practical implications for improving collaborative butterfly farming as an alternative to land-based economy.

Based on the preceding results we conclude that the patterns in which butterfly farmers seek, share and exchange information while working on butterfly farming project is highly influence by elements of social capital including group norms, established group structure, network of interactions and mutual benefits including social and economic incentives. Social capital theoretical lens can be used to provide frame of reference in understanding different farmers' information behavioural patterns such the use of people as sources of information, farmers' information and knowledge sharing and information and knowledge exchange. We also conclude that farming related tasks and activities influenced farmers' collaborative information behaviour, particularly on types of information needed, types of information to be accessed and shared. Based on observations and respondents' accounts on information and knowledge sharing, information and knowledge exchange, dialogic interactions, group based information seeking and high dependency on humans as sources of information, we conclude that farmers' information behavior is highly collaborative.

Collaborative information behaviour is a generic concept that includes multiple sub processes. This study only focused on shared information needs, collaborative information seeking, information and knowledge sharing and exchange. There is a need to replicate this study using mixed method approach to compare different projects within the framework of ICDP. Such studies would allow researchers to collect data that can support the generalization of the results and be able to draw robust conclusion from multiple ICDPs.

\section{ACKNOWLEGEMENT}

This research did not receive any grant from any funding agency in the public, commercial or not-for-profit sector.

Page | 26 


\section{REFERENCES}

Aina, L.O. 1991. Provision of agricultural information to farmers and extension officers: A catalyst in increased agricultural production in Africa. Quarterly Bulletin of IAALD, Vol. 36 no. 1/2: 20-23.

Amani Nature Reserve. 2012. Amani nature reserve and East Usambara mountain in Tanzania: Tips for responsible tourism. Available at http://wwf.fi/mediabank/2961.pdf.

Bates, M.J. 2010. Human information behavior. In Encyclopedia of Library and Information Sciences, 3rd Ed. Marcia J. Bates and Mary Niles Maack, Eds. New York: CRC Press, vol. 3, pp. 2381-2391

Byamugisha, H.M., Ikoja-Odongo, R., Nasinyama, G. W. and Lwasa, S. 2008. Information seeking and use among urban farmers in Kampala district, Uganda. Agriculture Information Worldwide, Vol. 1, no. 3: 94-101.

Byamugisha, H.M., Ikoja-Odongo, R., and Nasinyama, G.W. 2010. Information needs and use among urban farmers in Kampala City in Uganda. Library and Information Research. Vol. 34, no. 108:18-32.

Davies, R. 2013. Towards a model of information behavior of an information provider: $A$ mixed method study. PhD dissertation, Robert Gordon University, Aberdeen. Available at https://openair.rgu.ac.uk/handle/10059/831.

Engh, V. 2011. Integrated conservation and development projects and efforts around Amani nature reserve, Tanzania, and their effects on livelihoods and forest conservation. Master's thesis, Norwegian University of Life Sciences, Akershus.

Elly, T., and Silayo, E.E. 2013. Agricultural information needs and sources of the rural farmers in Tanzania: A case of Iringa rural district. Library Review, Vol. 6, no. 8/9: 547566.

Fawole, O.P. 2008. Pineapple farmers' information sources and usage in Nigeria. Bulgarian Journal of Agricultural Science, Vol. 14, no. 4: 381-389.

Harrison, L.A. 2009. Understanding the collaborative information-seeking practices of undergraduate students. Master's thesis, University of North Carolina at Chapel Hill, Chapel Hill.

Häuberer. J. 2011. Social capital theory: Towards a methodological foundation. Wiesbaden: VS Verlag für Sozialwissenschaften.

Hertzun, M. 2010. Breakdowns in collaborative information seeking: A study of the medication process. Information Processing and Management, Vol. 4: 646-655.

Iraba, M.L. and Venter, I.M. 2011. Empowerment of rural farmers through information sharing using inexpensive technologies. In Brown, I.; Sewchurran, K. and Suleman, H. (Eds). Knowledge, innovation and leadership in a diverse, multidisciplinary environment. Cape Town: Institute of Computer Scientists and Information Technologists: 279-282.

Jambiya, G. and Sossovele, H. 2001. Conservation and poverty: A case of Amani nature reserve. REPOA, Research Report no. 5. Dar es Salaam: Mkuki na Nyota Publishers.

Katungi, E. Edmeades, S. and Smale, M. 2006. Gender, social capital and information exchange in rural Uganda. Capri working paper no. 59. Available at http://www.ifpri.org/sites/default/files/publications/CAPRIWP59.pdf

Lwoga, E.T., Ngulube, P., and Stilwell, C. 2010. Information needs and information seeking behaviour of small-scale farmers in Tanzania, Innovation Vol. 10:82-103.

Lwoga, E.T., Stilwell, C. and Ngulube, P. 2011. Access and use of agricultural information and knowledge in Tanzania. Library Review, Vol. 60, no.5: 383-395.

Mashavave, T., Mapfumo, P., Mtambanegwe, F., Gwandu, T. and Siziba, S. 2009. Interaction patterns determining improved information and knowledge sharing among 
smallholder farmers. African Journal of Agricultural and Resource Economics, Vol. 8, no. 1: 1-12.

Matovelo, D.S., Msuya, J. and de Smet, E. 2006. Towards developing proactive information acquisition practices among smallholder farmers for empowerment and poverty reduction: A situation analysis. International Association of Agricultural Information Specialists (IAALD) Quarterly Bulletin, Vol. 51, no. 3/4.

Meyer, H.W.J. 2005. The nature of information, and the effective use of information in rural development. Information Research, Vol. 10, no. 2. Available at http://www.informationr.net/ir/10-2/paper214.html.

Morgan-Brown, T. 2007. Butterfly farming and conservation behavior in the East Usambara mountains of Tanzania. Master's Thesis, University of Florida, Florida. Available at http://www.amanibutterflyproject.org/morganbrown_t.pdf

Morgan-Brown, T., Jacobson, S. K., Wald, K. and Child, B. 2009. Quantitative assessment of a Tanzanian integrated conservation and development project involving butterfly farming. Conservation Biology, Vol. 24, no. 2: 563-572.

Munyua, $\mathrm{H}$ and Stilwell, C. 2010. A mixed qualitative-quantitative participatory methodology: A study of the agricultural knowledge and information system (AKIS) of small-scale farmers in Kirinyaga district, Kenya, Library Management, Vol. 31, no. 1\&2: 5-18.

Mwalukasa, N. 2013. Agricultural information sources used for climate change adaptation in Tanzania. Library Review, Vol. 62 no. 4/5: 266-292.

Ndumbaro, F. 2016. Collaborative information behaviour (CIB) of undergraduates in selected universities in Tanzania. PhD dissertation, University of Kwazulu Natal, Pietermaritzburg, South Africa.

Pilerot, O. 2012. LIS research on information sharing activities: People, places, or information. Journal of Documentation, Vol. 68, no. 4: 559-581.

Prekop, P. 2002. A qualitative study of collaborative information seeking. Journal of Documentation, Vol. 54, no. 5: 533-547.

Putnam, R. 1995. Bowling alone: America's declining social capital. Journal of Democracy, Vol. 6, no. 1:65-78.

Reddy, M. C. 2003. Time to work together: temporality, collaboration \& information seeking. PhD dissertation, University of California, California. Available at http://faculty.washington.edu/wpratt/Publications/Madhu_dissertation.pdf.

Rich, K.M., Rich, M. and Chengappa, G.P. 2014. The governance of global value chains for live butterflies. NUPI working paper 828. Available at http://www.nupi.no/content/download/494739/1644542/version/1/file/NUPI+WP828-Rich-Rich-Chengappa.pdf.

Saleh, N. 2012. Collaborative information seeking in learning tasks: A study of engineering students. PhD dissertation, McGill University, Montreal, Canada. Available at http://digitool.library.mcgill.ca/webclient/StreamGate?folder_id=0\&dvs=13958294001 74 605.

Schlaepfer, G.G. 2006. Butterflies. New York: Marshall Gavendish Benchmark.

Shah, C. 2013. Collaborative information seeking (CIS): Challenges and opportunities. Paper presented at the 3rd Workshop in Collaborative Information Seeking: Consolidating the past, creating the future, 24 February, 2013, at San Antonio, Texas.

Small, R. 2004. Uptake and the success of insect farming projects in Papua New Guinea: Implications for biodiversity conservation. MPhl Dissertation: University of Cambridge.

Sonnenwald, D.H. and Pierce, L.G. 2000. Information behavior in dynamic group work contexts: Interwoven situational awareness, dense social networks and contested 
collaboration in command and control. Information Processing and Management, Vol. 36, no. 3: 461-479.

Spence, P. R. 2005. Collaborative information seeking: A study of a patient care team in the emergence department. Master thesis. Missouri: University of Missouri-Rolla.

Sumodan, P.K. 2004. Butterfly farming: Considering the rich fauna of the colourful insects Kerala opens tremendous potentiality in butterfly farming. Kerala Calling, June: 27-29.

Tadesa, D. 2008. Access \& utilization of agricultural information by resettler farming households: The case of Metema Woreda, Borth Gondar, Ethiopia. Master's Thesis, Haramaya University, Ethiopia.

Talja, S. 2002. Information sharing in academic communities: Types and levels of collaboration in information seeking and use. New Review of Information Behavior Research, Vol. 3: 143-159.

Vihemaki, H. 2006. Development and conflicts of forest conservation in Africa: Participatory approaches and forest control in the East Usambara mountain. Available at http://www.helsinki.fi/kehitysmaatutkimus/tutkimus/Vihemakiwp.pdf.

Widén-Wulff, G., Ek, S., Ginman, M., Perttilä, R., Södergård, P. and Tötterman, A. 2008. Information behavior meets social capital: A conceptual model. Journal of Information Science, Vol. 34, no. 3: 346-355. 